\title{
Synthesis, coordination to Au(I) and photophysical properties of a novel polyfluorinated benzothiazolephosphine ligand $\dagger+$
}

\author{
Eduardo J. Fernández, ${ }^{* a}$ Antonio Laguna, ${ }^{* b}$ José M. López-de-Luzuriaga, ${ }^{a}$ Miguel Monge, ${ }^{a}$ Manuel Montiel, ${ }^{a}$ \\ M. Elena Olmos ${ }^{a}$ and María Rodríguez-Castillo ${ }^{a}$
}

\author{
Received 15th December 2005, Accepted 11th April 2006 \\ First published as an Advance Article on the web 25th April 2006 \\ DOI: 10.1039/b517728f
}

The reaction between $\mathrm{Ph}_{2} \mathrm{PH}$ and $\mathrm{C}_{6} \mathrm{~F}_{5} \mathrm{CNS}$ leads to the formation of the polyfluorinated benzothiazolephosphine ligand $\mathrm{Ph}_{2} \mathrm{P}(\mathrm{CNS})\left(\mathrm{C}_{6} \mathrm{~F}_{4}\right)$ 1. The mechanism of the reaction involves the addition of the phosphine to the isothiocyanate and subsequent intramolecular nucleophilic aromatic substitution. This new ligand reacts with gold(I) substrates producing complexes

$\left[\mathrm{AuCl}\left\{\mathrm{Ph}_{2} \mathrm{P}(\mathrm{CNS})\left(\mathrm{C}_{6} \mathrm{~F}_{4}\right)\right\}\right] 2$ and $\left[\mathrm{Au}\left(\mathrm{C}_{6} \mathrm{~F}_{5}\right)\left\{\mathrm{Ph}_{2} \mathrm{P}(\mathrm{CNS})\left(\mathrm{C}_{6} \mathrm{~F}_{4}\right)\right\}\right]$ 3. Both the ligand 1 and complexes 2 and 3 display phosphorescence with emissions arising from $\mathrm{n}(\mathrm{P}) \rightarrow \pi^{*}$ (heterocyclic ring) excited state for $\mathbf{1}$ and $\pi \rightarrow \pi^{*}$ (heterocyclic ring) excited state for $\mathbf{2}$ and $\mathbf{3}$. DFT and TD-DFT calculations agree with these results.

\section{Introduction}

Polyfunctional molecules bearing P-, N- and/or S-donor centres are suitable ligands for the coordination of one or various metal centres leading to homo- or heteropolynuclear compounds. Thus, it is possible to prepare a broad family of compounds that display very different structural arrangements and, in some cases, special physical properties associated with them. These may be used for a number of special applications including chemotherapy, diagnosis, electron microscopy and surface technology. ${ }^{1-5}$

As a part of our ongoing research, we focused on phosphinothioformamide ligands, ${ }^{6}$ prepared by reaction of isothiocyanates and diphenylphosphine (Scheme 1), since they can promote selective coordination to gold(I) via the phosphorus atom, but in the vicinity of other donor centres, leading to new and interesting structural arrangements, which are also influenced by the ability of $\mathrm{Au}(\mathrm{I})$ to promote aurophilic interactions.

The use of different alkyl or aryl isothiocyanates as starting materials permits, in principle, the preparation of new phosphinothioformamide ligands varying the substituents at nitrogen and/or phosphorus sites, which leads to variations in their electronic properties and, hence, in their coordination abilities. In this sense, we thought that the use of the isothiocyanate $\mathrm{C}_{6} \mathrm{~F}_{5}-\mathrm{N}=\mathrm{C}=\mathrm{S}$ as starting material would lead to a new type of phosphinothioformamide ligand with different donor properties compared to the already reported with $\mathrm{Me}$ - or $\mathrm{Ph}$-substituents, taking into account the higher electron accepting properties of the polyfluoroaromatic ring. Nevertheless, the addition of $\mathrm{PPh}_{2} \mathrm{H}$ to $\mathrm{C}_{6} \mathrm{~F}_{5}-\mathrm{N}=\mathrm{C}=\mathrm{S}$ pro-

${ }^{a}$ Departamento de Química, Universidad de La Rioja, Grupo de Síntesis Química de La Rioja, UA-CSIC. Complejo Científico-Tecnológico, 26004, Logroño,Spain.E-mail: eduardo.fernandez@dq.unirioja.es

${ }^{b}$ Departamento de Química Inorgánica, Instituto de Ciencia de Materiales de Aragón, Universidad de Zaragoza-CSIC, 50009, Zaragoza, Spain. E-mail: alaguna@posta.unizar.es; Fax: +34 976 761187; Tel: +34976 761185

$\dagger$ Dedicated to Professor Antonio Garcia on the occasion of his 65th birthday.

\$ Electronic supplementary information (ESI) available: NMR for 1 (Fig. S1); TDDFT excitations and MOs for 1a and 3a (Fig. S2-S5); population analysis (Tables S1-S2). See DOI: 10.1039/b517728f
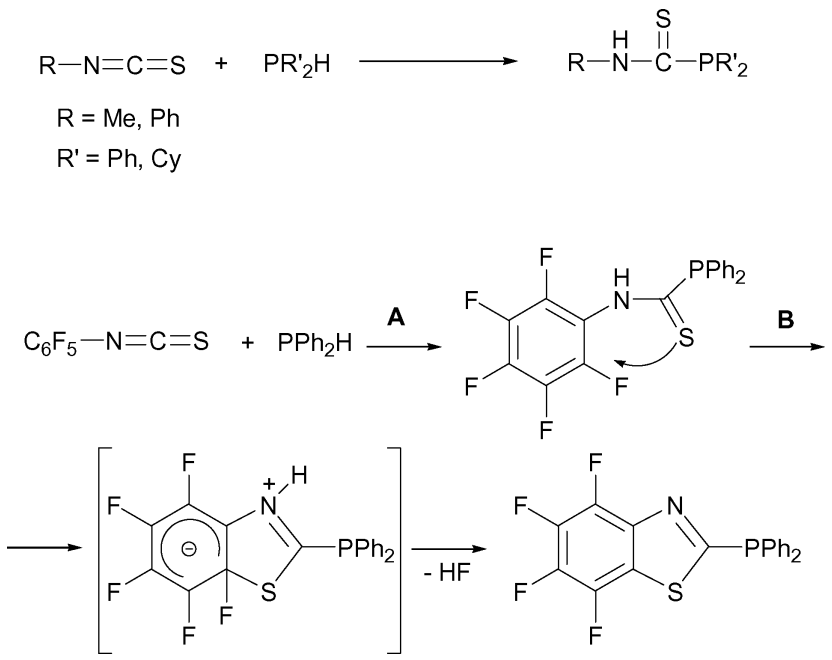

Scheme 1 General synthesis of phosphinothioformamide ligands and mechanism of addition (A) and intramolecular aromatic nucleophilic substitution (B) for the formation of the phosphinobenzothiazole ligand.

duces a phosphinotetrafluorobenzothiazole ligand in quantitative yield by initial formation of the desired phosphinothioformamide ligand (see above) and a subsequent secondary transformation consisting of an intramolecular nucleophilic substitution of fluorine leading to the thiazole ring (Scheme 1). This result seems to be favoured by the characteristics of the pentafluorophenyl ring, since the electronegativity of fluorine favours nucleophilic attack on the electrophilic carbon centre and at the same time fluorine has been reported to be a good leaving atom. This type of perfluorobenzothiazole moiety has been reported as a secondary product in the addition reaction of thiourea to $\mathrm{C}_{6} \mathrm{~F}_{5}-$ $\mathrm{N}=\mathrm{CClR}\left(\mathrm{R}=\mathrm{C}_{6} \mathrm{H}_{5}, \mathrm{C}_{6} \mathrm{~F}_{5}\right)$ leading to aryl substituted perfluorobenzothiazoles following a similar addition plus intramolecular nucleophilic aromatic substitution mechanism. ${ }^{7}$ Also, the intramolecular cyclation of $N$-pentafluorophenylthioamides leads to perfluorobenzothiazole units. ${ }^{8}$ 


\section{Results and discussion}

The ligand diphenylphosphinotetrafluorobenzothiazole $\mathrm{Ph}_{2} \mathrm{P}$ $(\mathrm{CNS})\left(\mathrm{C}_{6} \mathrm{~F}_{4}\right) \mathbf{1}$ is synthesized by refluxing in toluene an equimolecular mixture of diphenylphosphine and pentafluorophenylisothiocyanate under an argon atmosphere. The control of the reaction through ${ }^{31} \mathrm{P}\left\{{ }^{1} \mathrm{H}\right\},{ }^{19} \mathrm{~F}$ and ${ }^{1} \mathrm{H}$ NMR spectroscopy and mass spectrometry allows us to gain insight about the mechanism of formation of this new ligand. Thus, for instance, after three hours of reaction three species are observed in the ${ }^{31} \mathrm{P}\left\{{ }^{1} \mathrm{H}\right\}$ spectrum, which correspond to the starting $\mathrm{Ph}_{2} \mathrm{PH}$, the final benzothiazole 1 and a signal at $21 \mathrm{ppm}$ that can be assigned to the phosphinothioformamide ligand $\mathrm{C}_{6} \mathrm{~F}_{5}-\mathrm{N}(\mathrm{H}) \mathrm{C}(\mathrm{S}) \mathrm{PPh}_{2}$. The presence of this derivative is confirmed by the ${ }^{19} \mathrm{~F}$ and ${ }^{1} \mathrm{H}$ NMR spectra, since in the former three additional signals to those of the starting material and the final product at $-142.61,-153.43$ and $-161.62 \mathrm{ppm}$, corresponding to the pentaflourophenyl group, are observed; and the $\mathrm{N}-\mathrm{H}$ proton appears at $8.12 \mathrm{ppm}$ in its ${ }^{1} \mathrm{H}$ NMR spectrum. Also, the mass spectrum displays the corresponding peak at $m / z=412(100 \%)\left[\mathrm{C}_{6} \mathrm{~F}_{5}-\mathrm{N}(\mathrm{H}) \mathrm{C}(\mathrm{S}) \mathrm{PPh}_{2}+\mathrm{H}\right]^{+}$. At $t=0$ the ${ }^{31} \mathrm{P}\left\{{ }^{1} \mathrm{H}\right\}$ NMR spectrum displays the signals corresponding to the free diphenylphosphine and the dithioformamide intermediate and after 6 hours the only product is the benzothiazole ligand. These data support the mechanism of addition and subsequent intramolecular nucleophilic aromatic substitution by initial formation of the dithioformamide species.

The ligand $\mathrm{Ph}_{2} \mathrm{P}(\mathrm{CNS})\left(\mathrm{C}_{6} \mathrm{~F}_{4}\right)$ reacts with gold(I) starting materials such as $[\mathrm{AuCl}(\mathrm{tht})]$ or $\left[\mathrm{Au}\left(\mathrm{C}_{6} \mathrm{~F}_{5}\right)(\right.$ tht $\left.)\right]$ (tht $=$ tetrahydrothiophene) in a $1: 1$ molar ratio, leading to compounds of stoichiometry $\left[\mathrm{AuCl}\left\{\mathrm{Ph}_{2} \mathrm{P}(\mathrm{CNS})\left(\mathrm{C}_{6} \mathrm{~F}_{4}\right)\right\}\right] \mathbf{2}$ or $\left[\mathrm{Au}\left(\mathrm{C}_{6} \mathrm{~F}_{5}\right)\left\{\mathrm{Ph}_{2} \mathrm{P}\right.\right.$ (CNS) $\left.\left.\left(\mathrm{C}_{6} \mathrm{~F}_{4}\right)\right\}\right]$ 3, respectively, by displacement of the labile ligand tht. All physical and spectroscopic properties are in accordance with the proposed stoichiometries and both crystal structures have been established by X-ray diffraction studies.

By layering a dichloromethane solution of $\mathbf{2}$ with diethyl ether or by slow evaporation of a $\mathrm{CDCl}_{3}$ solution of $\mathbf{3}$, single crystals suitable for X-ray diffraction studies were obtained. Fig. 1 and 2 show the molecular structures and Tables 1 and 2 contain selected

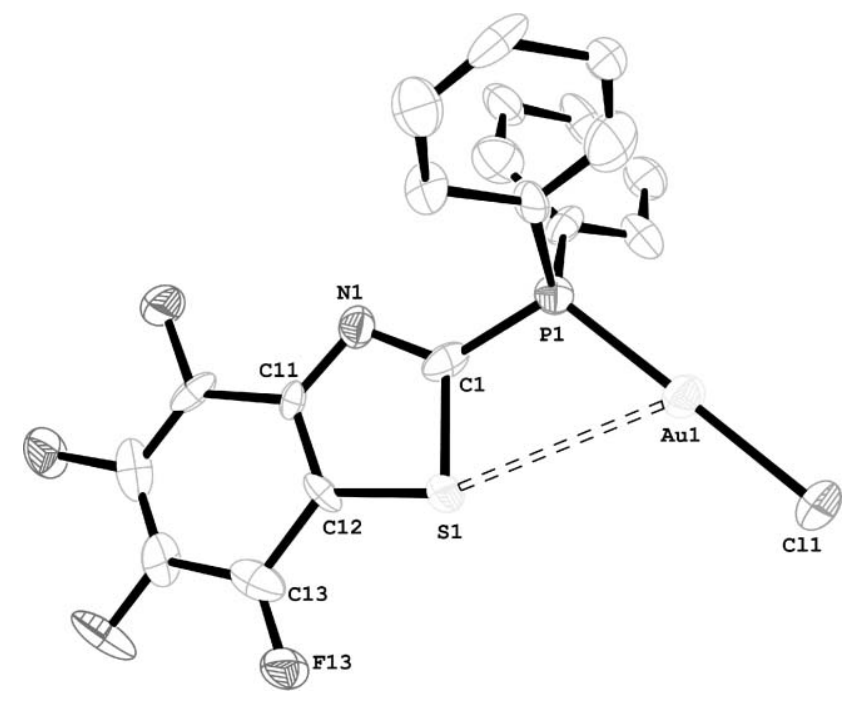

Fig. 1 The molecule of complex $\mathbf{2}$ in the crystal showing the numbering scheme. Hydrogen atoms have been omitted for clarity.

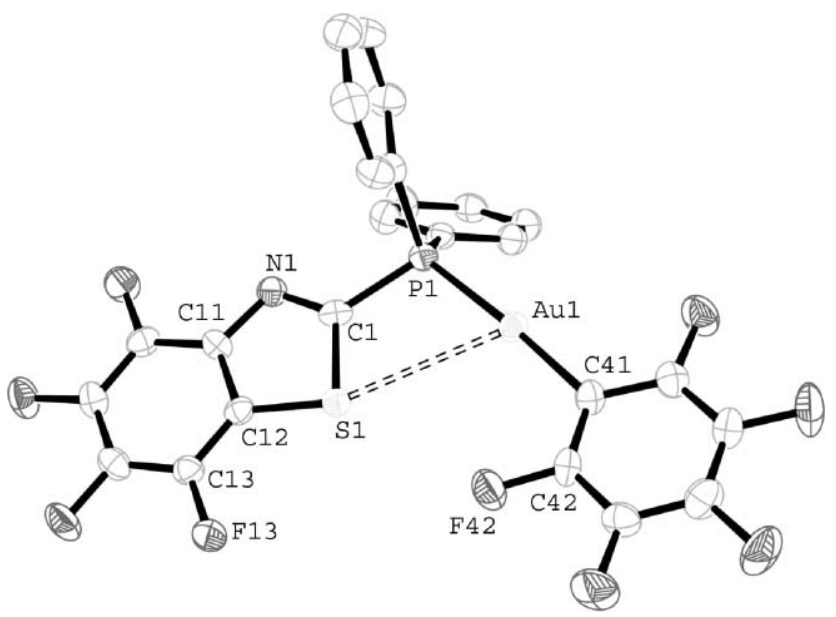

Fig. 2 The molecule of complex $\mathbf{3}$ in the crystal showing the numbering scheme. Hydrogen atoms have been omitted for clarity.

Table 1 Selected bond lengths $[\AA]$ and angles $\left[{ }^{\circ}\right]$ for complex 2

\begin{tabular}{lclr}
$\mathrm{Au}-\mathrm{P}$ & $2.2252(12)$ & $\mathrm{C}(1)-\mathrm{N}$ & $1.302(6)$ \\
$\mathrm{Au}-\mathrm{Cl}$ & $2.2759(13)$ & $\mathrm{C}(1)-\mathrm{S}$ & $1.753(5)$ \\
$\mathrm{P}-\mathrm{C}(21)$ & $1.807(5)$ & $\mathrm{S}-\mathrm{C}(11)$ & $1.729(5)$ \\
$\mathrm{P}-\mathrm{C}(31)$ & $1.808(5)$ & $\mathrm{N}-\mathrm{C}(12)$ & $1.381(6)$ \\
$\mathrm{P}-\mathrm{C}(1)$ & $1.817(5)$ & & \\
$\mathrm{P}-\mathrm{Au}-\mathrm{Cl}$ & $177.87(5)$ & $\mathrm{S}-\mathrm{C}(1)-\mathrm{P}$ & $118.7(3)$ \\
$\mathrm{N}-\mathrm{C}(1)-\mathrm{S}$ & $116.6(3)$ & $\mathrm{C}(11)-\mathrm{S}-\mathrm{C}(1)$ & $88.3(2)$ \\
$\mathrm{N}-\mathrm{C}(1)-\mathrm{P}$ & $124.7(4)$ & $\mathrm{C}(1)-\mathrm{N}-\mathrm{C}(12)$ & $109.7(4)$ \\
\hline
\end{tabular}

Table 2 Selected bond lengths $[\AA]$ and angles $\left[{ }^{\circ}\right]$ for complex 3

\begin{tabular}{lclc}
\hline $\mathrm{Au}-\mathrm{C}(41)$ & $2.054(3)$ & $\mathrm{C}(1)-\mathrm{N}$ & $1.299(4)$ \\
$\mathrm{Au}-\mathrm{P}$ & $2.2798(8)$ & $\mathrm{C}(1)-\mathrm{S}$ & $1.757(3)$ \\
$\mathrm{P}-\mathrm{C}(31)$ & $1.812(4)$ & $\mathrm{N}-\mathrm{C}(11)$ & $1.382(4)$ \\
$\mathrm{P}-\mathrm{C}(21)$ & $1.813(3)$ & $\mathrm{S}-\mathrm{C}(12)$ & $1.730(3)$ \\
$\mathrm{P}-\mathrm{C}(1)$ & $1.836(4)$ & & \\
$\mathrm{C}(41)-\mathrm{Au}-\mathrm{P}$ & $175.59(10)$ & $\mathrm{S}-\mathrm{C}(1)-\mathrm{P}$ & $117.49(18)$ \\
$\mathrm{N}-\mathrm{C}(1)-\mathrm{S}$ & $116.4(3)$ & $\mathrm{C}(1)-\mathrm{N}-\mathrm{C}(11)$ & $110.3(3)$ \\
$\mathrm{N}-\mathrm{C}(1)-\mathrm{P}$ & $125.9(3)$ & $\mathrm{C}(12)-\mathrm{S}-\mathrm{C}(1)$ & $88.49(16)$ \\
\hline
\end{tabular}

bond distances and angles for $\mathbf{2}$ and $\mathbf{3}$, respectively. The crystal structures consist of mononuclear $\left[\mathrm{AuX}\left\{\mathrm{Ph}_{2} \mathrm{P}(\mathrm{CNS})\left(\mathrm{C}_{6} \mathrm{~F}_{4}\right)\right\}\right](\mathrm{X}=$ $\left.\mathrm{Cl}(2), \mathrm{C}_{6} \mathrm{~F}_{5}(3)\right)$ units, with the gold(I) centre linearly coordinated to $\mathrm{Cl}$ (2) or $\mathrm{C}_{6} \mathrm{~F}_{5}$ (3) and to the phosphorus atom of the benzothiazolephosphine ligand with a maximum deviation from linearity of $4.41^{\circ}$ in 3 .

The Au-P distances of 2.2252(12) (2) or 2.2798(8) $\AA$ (3) are very close to those observed for other related complexes containing the fragment $\mathrm{Cl}-\mathrm{Au}-\mathrm{P}$ or $\mathrm{C}_{6} \mathrm{~F}_{5}-\mathrm{Au}-\mathrm{P},{ }^{6 a, 9}$ such as $\left[\mathrm{Mo}(\mathrm{CO})_{4}\left\{\left(\mathrm{PPh}_{2}\right)_{2}\right.\right.$ $\left.\left.\mathrm{CHPPh}_{2}\right\} \mathrm{AuCl}\right] \quad(2.225(2) \AA \AA),{ }^{9 a} \quad\left[\mathrm{Mo}(\mathrm{CO})_{4}\left\{\left(\mathrm{PPh}_{2} \mathrm{CH}_{2}\right)_{2} \mathrm{CMe}-\right.\right.$ $\left.\left.\left(\mathrm{CH}_{2} \mathrm{PPh}_{2}\right)\right\} \mathrm{AuCl}\right](2.232(2) \AA)^{9 b}$ and $[\mathrm{AuCl}\{\mathrm{Ph} 2 \mathrm{PC}(\mathrm{S}) \mathrm{N}(\mathrm{H}) \mathrm{Me}\}]$ $(2.2254(7) \AA)^{6 a}$ or $\left[\mathrm{Mo}(\mathrm{CO})_{4}\left\{\left(\mathrm{PPh}_{2}\right)_{2} \mathrm{CHPPh}_{2}\right\} \mathrm{Au}\left(\mathrm{C}_{6} \mathrm{~F}_{5}\right)\right]$ $(2.274(2) \AA),{ }^{9 a} \quad\left[\mathrm{NBu}_{4}\right] \quad\left[\mathrm{Mo}(\mathrm{CO})_{4}\left\{\left(\mathrm{PPh}_{2}\right)_{2} \mathrm{CPPh}_{2}\right\} \mathrm{Au}\left(\mathrm{C}_{6} \mathrm{~F}_{5}\right)\right]$ $(2.283(2) \AA)^{9 a}$ and $\left[\mathrm{Au}_{2}\left(\mathrm{C}_{6} \mathrm{~F}_{5}\right)_{2}\{\mathrm{Ph} 2 \mathrm{PC}(\mathrm{S}) \mathrm{N}(\mathrm{H}) \mathrm{Me}\}\right]_{2}(2.270(2)-$ $2.316(2) \AA),{ }^{6 a}$ respectively, and show a higher trans influence of the $\mathrm{C}_{6} \mathrm{~F}_{5}$ group when compared to the chlorine atom.

Regarding the $\mathrm{Au}-\mathrm{Cl}$ and $\mathrm{Au}-\mathrm{C}$ bond lengths, of 2.2759(13) (2) and 2.054(3) $\AA$ (3), respectively, they are also similar to those found in the compounds mentioned above (from 2.275(1) to 2.2866(8) $\AA$ for $\mathrm{Au}-\mathrm{Cl}$ and from 2.041(8) to 2.074(7) $\AA$ for $\mathrm{Au}-\mathrm{C}){ }^{6 a, 9}$ 
Table 3 Spectroscopic and photophysical properties of 1-3

\begin{tabular}{|c|c|c|c|}
\hline Complex & Medium $(T / \mathrm{K})$ & $\lambda_{\mathrm{abs}}^{b} / \mathrm{nm}\left(\varepsilon / \mathrm{mol}^{-1} \mathrm{dm}^{3} \mathrm{~cm}^{-1}\right)$ & $\lambda_{\mathrm{em}}\left(\lambda_{\mathrm{exc}}\right) / \mathrm{nm}[\tau / \mu \mathrm{s}]$ \\
\hline \multirow[t]{3}{*}{1} & $\mathrm{CH}_{2} \mathrm{Cl}_{2}(298)$ & \multirow[t]{3}{*}{$233\left(4.28 \times 10^{4}\right), 268\left(2.38 \times 10^{4}\right), 297\left(3.60 \times 10^{4}\right)$} & Non-emissive \\
\hline & Solid (298) & & $510(350)[10.6]$ \\
\hline & Glass $^{a}(77)$ & & $506(320)$ \\
\hline \multirow[t]{2}{*}{2} & $\mathrm{CH}_{2} \mathrm{Cl}_{2}(298)$ & \multirow[t]{2}{*}{$239\left(4.86 \times 10^{4}\right), 278\left(2.26 \times 10^{4}\right)$} & Non-emissive \\
\hline & Solid (298) & & $473(340)[152.6,9.1]$ \\
\hline \multirow{3}{*}{3} & Solid (298) & \multirow{3}{*}{$242\left(6.52 \times 10^{4}\right), 278\left(3.34 \times 10^{4}\right)$} & $484(350)[44.8,13.4]$ \\
\hline & Solid (77) & & $453,481,511(342)$ \\
\hline & Glass $^{a}(77)$ & & $445,474,507(310)$ \\
\hline
\end{tabular}

${ }^{a} \mathrm{EtOH} / \mathrm{MeOH} / \mathrm{CH}_{2} \mathrm{Cl}_{2}$ (v/v/v, $\left.8: 2: 1\right) .{ }^{b} 5 \times 10^{-5} \mathrm{M}$ in $\mathrm{CH}_{2} \mathrm{Cl}_{2}$.

The bond lengths and angles within the thiazole ring compare well with those found in other derivatives containing this group. ${ }^{10}$

Finally, both crystal structures also show intramolecular $\mathrm{Au}$...S weak interactions of 3.4603(12) (2) or 3.3409(9) $\AA$ (3), which are of the same order of magnitude as the $\mathrm{Au}-\mathrm{S}$ distances observed in $\left[\mathrm{Au}_{2}\left(\mathrm{Ph}_{2} \mathrm{P}\left(\mathrm{CH}_{2}\right)_{6} \mathrm{PPh}_{2}\right)_{6}\left(\left\{\mathrm{C}_{6} \mathrm{H}_{3}\left(\mathrm{NH}_{2}\right)\right\}\{\mathrm{CNS}\} \mathrm{S}\right)_{2}\right]$ or $\left[\mathrm{Au}\left(\mathrm{P}\left(\mathrm{CH}_{2} \mathrm{CH}_{2} \mathrm{CN}\right)_{3}\right)\left(\left\{\mathrm{C}_{6} \mathrm{H}_{3}\left(\mathrm{NH}_{2}\right)\right\}\{\mathrm{CNS}\} \mathrm{S}\right)_{2}\right](3.28-3.57 \AA) .{ }^{11}$

On the other hand, benzothiazole ligands are known to display interesting photophysical properties improving the photostability and emission intensity in conjugated systems as well as in the complexes that contain them. ${ }^{12,13}$ Also, the presence of gold(I) in the complexes should enhance the phosphorescence and, on the other hand, fluorinated materials facilitate thin film fabrication and offer thermal and oxidative stability. ${ }^{14-20}$ These are important characteristics in the products used as emitting materials for lightemitting devices (LED's).

The benzothiazole ligand $\mathbf{1}$ as well as the complexes $\mathbf{2}$ and $\mathbf{3}$ exhibit bright luminescence in the solid state at room temperature and at $77 \mathrm{~K}$ and in glass media at $77 \mathrm{~K}$ (see Fig. 3 and Table 3), but neither in deoxygenated dichloromethane nor in acetonitrile solutions. The absorption spectra for the three compounds in $\mathrm{CH}_{2} \mathrm{Cl}_{2}$ show similar bands at high energy for the ligand and both complexes ( $\varepsilon$ of the order $10^{4} \mathrm{dm}^{3} \mathrm{~mol}^{-1} \mathrm{~cm}^{-1}$ ) in the UV

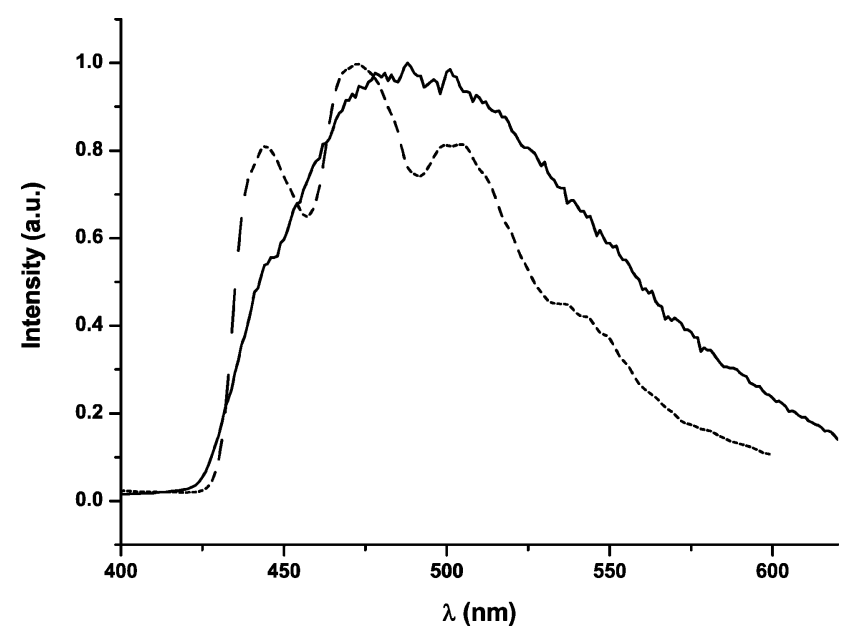

Fig. 3 Emission spectra of $\mathbf{1}$ (solid line) and $\mathbf{3}$ (dashed line) in alcohol glass at $77 \mathrm{~K}$. region and, in addition, the ligand displays a lower energy band at $297 \mathrm{~nm}$. The fact that the higher energy bands are similar for the complexes and the ligand suggests intraligand ${ }^{1} \mathrm{IL}\left(\pi \rightarrow \pi^{*}\right)(\mathrm{N}-\mathrm{C})$ transitions. Similar assignments in related benzothiazole ligands have been reported previously. ${ }^{12}$ The band placed at lower energy is tentatively assigned to a ${ }^{1} \mathrm{IL}\left(\mathrm{n} \rightarrow \pi^{*}\right)$ transition, which is absent in the case of the gold complexes. Theoretical TD-DFT calculations (see below) agree with this assumption. The excitation peaks in the solid state are red shifted from the absorption bands seen in solution suggesting spin-forbidden transitions. Also, the lifetime measurements, in the solid state at room temperature, in the microsecond range are consistent with this and, therefore, with phosphorescence. The presence of gold in the complexes seems to affect the luminescence increasing the intensity of the emission and the lifetime of the excited states responsible for it.

The emission bands for complexes $\mathbf{2}$ and $\mathbf{3}$ at $77 \mathrm{~K}$ in the solid state and in an alcohol glass appear at similar energies and with similar structures. Both display peaks in the ranges 445-461, $474-488$ and $507-516 \mathrm{~nm}$ with tailing extending to $c a .600 \mathrm{~nm}$, nevertheless, in the case of ligand $\mathbf{1}$ the emission is broad and unstructured even at low temperatures (see Fig. 3) The spacing between peaks in the case of complexes 2 and 3 is about $1400 \mathrm{~cm}^{-1}$, which is assigned to a vibrational mode of the heterocyclic ring of the ligand, which also appear in their IR spectra. These facts are indicative of different origins of the excited states in the ligand and in the gold complexes. Thus, while the anionic ligand bonded to gold $\left(\mathrm{Cl} \mathrm{2}, \mathrm{C}_{6} \mathrm{~F}_{5} 3\right)$ seems not to affect the transitions, since one would expect a bigger difference in the energy of the emissions for both complexes, the presence of the gold centre must influence the electronic structure of the ligand, because the emission appears at different energy and does not show any structure. Therefore, what seems likely is that in the case of the free ligand the origin of the transition is the free electron pair of the unsaturated phosphorous atom giving rise to a $\mathrm{n}(\mathrm{P}) \rightarrow \pi^{*}$ (heterocyclic ring) excited state, while the coordination of this phosphorus to the gold centre leads to a gold-perturbed $\pi \rightarrow \pi^{*}$ (heterocyclic ring) excited states in the complexes $\mathbf{2}$ and $\mathbf{3}$, respectively.

These results are supported by the analyses of the molecular orbitals and the theoretical excitations obtained by DFT and TDDFT calculations, respectively. Taking into account the accessible computational costs we have used as a theoretical model system 3a, the molecular geometry of which has been obtained through 
X-ray diffraction analysis for complex 3, that represents the photophysical behaviour of complexes $\mathbf{2}$ and $\mathbf{3}$ and a fully DFTB3LYP optimized model system 1a that represents ligand $\mathbf{1}$.

In order to reproduce theoretically the absorption spectra of ligand 1 and complex 3 we carried out time-dependent DFT calculations of the first few singlet excitations for models 1a and 3a (see ESIt for 1a). The obtained results confirm the above mentioned character of the spin allowed transitions observed experimentally. Thus, for the ligand 1 the character of the occupied orbitals involved in these excitations agree well with a $\mathrm{n}(\mathrm{P})$ character for the low energy band at $297 \mathrm{~nm}$ and a $\pi$ character for the high energy bands at 233 and $268 \mathrm{~nm}$, meanwhile for complex 3 a $\pi$ character (slightly gold-perturbed) for the bands at 242 and $278 \mathrm{~nm}$ is observed. The $\pi^{*}$ character for the empty orbitals is also confirmed in both cases. Moreover, the energy of the oscillator strengths for the predicted theoretical excitations for models 1a and 3a clearly matches the experimental ones (see Fig. 4 for model 3a).

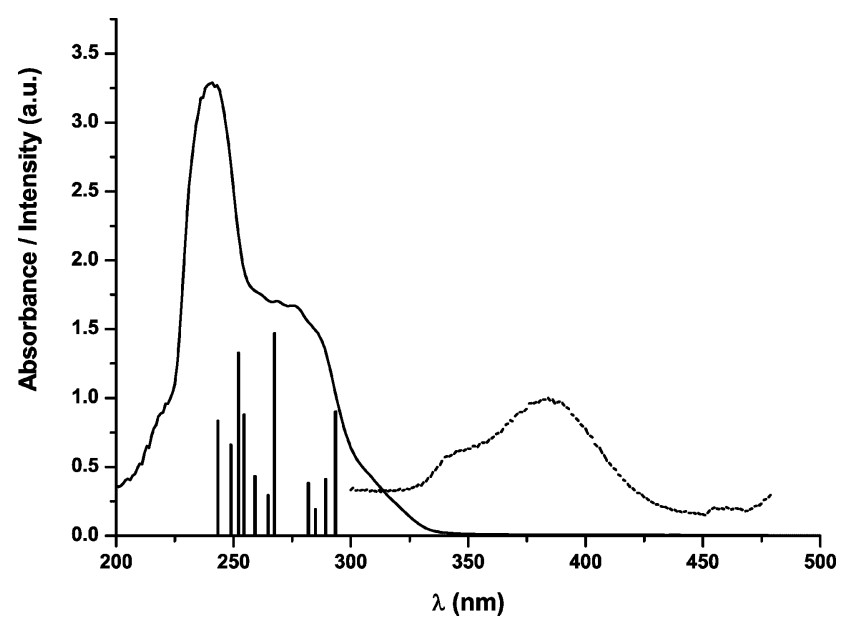

Fig. 4 Absorption spectrum (solid line) of 3 in $5 \times 10^{-5} \mathrm{M} \mathrm{CH}_{2} \mathrm{Cl}_{2}$ solution, first few theoretical singlet excitations of model 3a (bars) and experimental excitation spectrum of $\mathbf{3}$ (dashed line) in the solid state at room temperature.

As we have mentioned before, the experimental excitation peaks responsible for the emissions of 1-3 in the solid state are red shifted from the absorption bands suggesting spin-forbidden transitions. In this sense, we have used TD-DFT calculations to predict the energy of the lowest triplet excitation for each case that could be assigned to the experimental energy excitation that leads to phosphorescence (Fig. 5).

From the photophysical measurements at low temperature in the solid state and in glassy solution a different behaviour is observed for the ligand $\mathbf{1}$ and for the complexes $\mathbf{2}$ and $\mathbf{3}$. The unstructured emission band observed for the ligand could be assigned to the theoretical triplet transition between the 99a and 100a orbitals (see Fig. 5) at $352 \mathrm{~nm}$ (experimental: $350 \mathrm{~nm}$ ) leading to a $\mathrm{n}(\mathrm{P}) \rightarrow$ $\pi^{*}$ transition as predicted experimentally. On the other hand the structured emission for $\mathbf{3}$, consistent with starting orbitals located at the heterocyclic ring, is in agreement with the theoretical triplet transition that, upon coordination of the $\mathrm{P}$ atom to the gold fragment, takes place between $\pi$ (147a) and $\pi^{*}$ (150a) orbitals

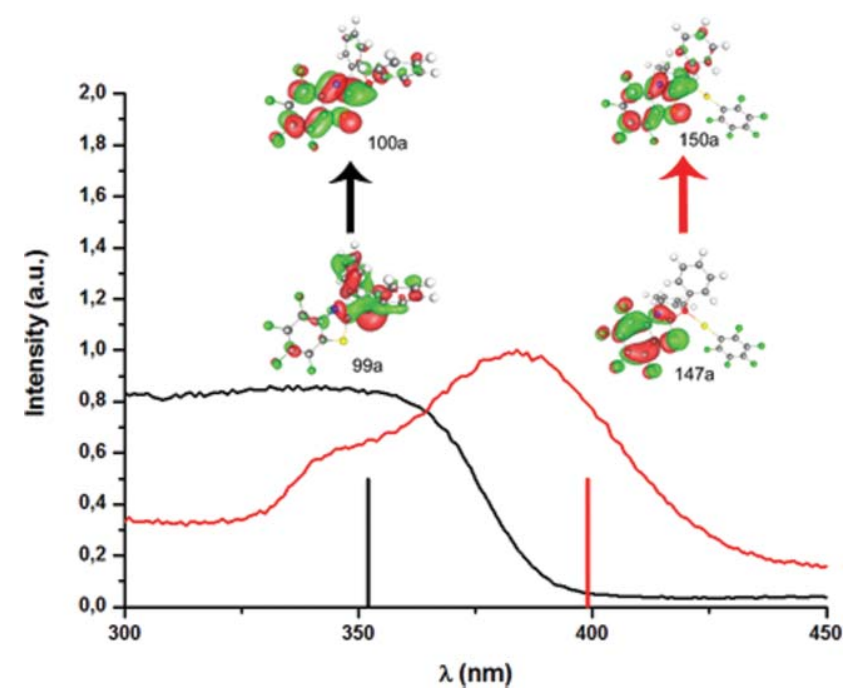

Fig. 5 Experimental excitation spectra of $\mathbf{1}$ (black) and $\mathbf{3}$ (red) and first triplet excitation (only energy positions) for models $\mathbf{1 a}$ (black) and $\mathbf{3 a}$ (red).

of the $\mathrm{C}_{6} \mathrm{~F}_{4}(\mathrm{CNS})$ heterocyclic ring at $399 \mathrm{~nm}$ (experimental: $388 \mathrm{~nm})$.

\section{Experimental}

\section{General}

The compounds $[\mathrm{AuCl}(\mathrm{tht})]^{21}$ and $\left[\mathrm{Au}\left(\mathrm{C}_{6} \mathrm{~F}_{5}\right)(\mathrm{tht})\right]^{22}$ were prepared by literature methods. The starting materials $\mathrm{PPh}_{2} \mathrm{H}$ and $\mathrm{C}_{6} \mathrm{~F}_{5} \mathrm{NCS}$ were purchased from Sigma-Aldrich and used as received.

\section{Instrumentation}

Infrared spectra were recorded in the $4000-200 \mathrm{~cm}^{-1}$ range on a Perkin-Elmer FT-IR Spectrum 1000 spectrophotometer, using Nujol mulls between polyethylene sheets. C, H, N, S analyses were carried out with a C.E. Instrument EA-1110 CHNS-O microanalyser. Mass spectra were recorded on a HP-5989B Mass Spectrometer API-Electrospray with interface 59987A. ${ }^{1} \mathrm{H}$, ${ }^{19} \mathrm{~F}$, and ${ }^{31} \mathrm{P}\left\{{ }^{1} \mathrm{H}\right\}$ NMR spectra were recorded on a Bruker ARX 300 in $\mathrm{CDCl}_{3}$ or $\mathrm{d}_{8}$-toluene solutions. Chemical shifts are quoted relative to $\mathrm{SiMe}_{4}\left({ }^{1} \mathrm{H}\right.$ external $), \mathrm{CFCl}_{3}\left({ }^{19} \mathrm{~F}\right.$ external) and $\mathrm{H}_{3} \mathrm{PO}_{4}(85 \%)\left({ }^{31} \mathrm{P}\right.$, external). Absorption spectra in solution were registered on a Hewlett Packard 8453 Diode Array UV-visible spectrophotometer. Excitation and emission spectra as well as lifetime measurements were recorded with a Jobin-Yvon Horiba Fluorolog 3-22 Tau-3 spectrofluorimeter.

\section{Synthesis}

$\mathbf{P h}_{2} \mathbf{P}(\mathrm{CNS})\left(\mathbf{C}_{6} \mathbf{F}_{4}\right)$ (1). To a solution of $\left(\mathrm{C}_{6} \mathrm{~F}_{5}\right) \mathrm{NCS}(0.6 \mathrm{~mL}$, $3.54 \mathrm{mmol})$ in $30 \mathrm{~mL}$ of toluene was added $\mathrm{Ph}_{2} \mathrm{PH}(0.5 \mathrm{~mL}$, $3.54 \mathrm{mmol}$ ) under an Argon atmosphere. The resulting yellow solution was heated under reflux for 6 hours and then cooled to room temperature. The solvent was removed in vacuo, and the yellow oily residue was treated with ethanol. Then, the solution was cooled in the refrigerator until yellow crystals of $\mathbf{1}$ appeared. Yield: $0.65 \mathrm{~g}(46.9 \%)$. Mass spectrum: $[\mathrm{M}+\mathrm{H}]^{+}$at $m / z=392$. Anal. Calcd. for $\mathrm{C}_{19} \mathrm{H}_{10} \mathrm{~F}_{4} \mathrm{NPS} \cdot 0.5 \mathrm{EtOH}$ : C, 57.98; H, 3.16; N, 3.39 ; S, 7.73. Found C, 58.44; H, 3.17; N, 3.57; S, 7.90\%. IR: 
$1337 \mathrm{~cm}^{-1}$ (heterocyclic ring). ${ }^{31} \mathrm{P}\left\{{ }^{1} \mathrm{H}\right\} \mathrm{NMR}\left(\mathrm{CDCl}_{3}\right) \delta:-6.35$ (s). ${ }^{19} \mathrm{~F} \mathrm{NMR}\left(\mathrm{CDCl}_{3}\right) \delta:-137.63[\mathrm{~m}, 1 \mathrm{~F}, o-\mathrm{S}],-146.56[\mathrm{~m}, 1 \mathrm{~F}, o-\mathrm{N}]$, $-157.72[\mathrm{~m}, 1 \mathrm{~F}, p-\mathrm{S}],-158.68[\mathrm{~m}, 1 \mathrm{~F}, p-\mathrm{N}]{ }^{1} \mathrm{H} \mathrm{NMR}\left(\mathrm{CDCl}_{3}\right) \delta$ : 7.56-7.41 [m, aromatic protons].

[AuCl$\left.\left\{\mathbf{P h}_{2} \mathbf{P}(\mathbf{C N S})\left(\mathbf{C}_{6} \mathbf{F}_{4}\right)\right\}\right]$ (2). To a dichloromethane solution $(20 \mathrm{~mL})$ of $[\mathrm{AuCl}(\mathrm{tht})](0.08 \mathrm{~g}, 0.255 \mathrm{mmol})$ was added $\mathrm{C}_{6} \mathrm{~F}_{4} \mathrm{NCSPPh}_{2}(0.1 \mathrm{~g}, 0.255 \mathrm{mmol})$ and after 30 minutes of stirring the solvent was evaporated to $c a .5 \mathrm{~mL}$. Addition of $n$-hexane $(20 \mathrm{~mL})$ led to precipitation of complex 2 as a white solid. Yield: $0.14 \mathrm{~g}(89.8 \%)$. Mass spectrum: $[\mathrm{M}-\mathrm{Cl}]^{+}$at $\mathrm{m} / \mathrm{z}=588.6$. Anal. Calcd for $\mathrm{C}_{19} \mathrm{H}_{10} \mathrm{AuClF}_{4} \mathrm{NPS}$ : C, 36.59; H, 1.62; N, 2.24; S, 5.14. Found C, 36.45; H, 1.65; N, 2.31; S, 4.95\%. IR: $1335 \mathrm{~cm}^{-1}$ (heterocyclic ring), $342 \mathrm{~cm}^{-1}(\mathrm{Au}-\mathrm{Cl}) .{ }^{31} \mathrm{P}\left\{{ }^{1} \mathrm{H}\right\} \mathrm{NMR}\left(\mathrm{CDCl}_{3}\right) \delta$ : 23.33 (s). ${ }^{19} \mathrm{~F}$ NMR $\left(\mathrm{CDCl}_{3}\right) \delta:-136.27[\mathrm{~m}, 1 \mathrm{~F}, o-\mathrm{S}],-144.22$ $[\mathrm{m}, 1 \mathrm{~F}, o-\mathrm{N}],-154.36[\mathrm{~m}, 1 \mathrm{~F}, p-\mathrm{S}],-155.05[\mathrm{~m}, 1 \mathrm{~F}, p-\mathrm{N}]{ }^{1} \mathrm{H}$ $\mathrm{NMR}\left(\mathrm{CDCl}_{3}\right) \delta: 7.88-7.25$ [m, aromatic protons].

Crystal data for 2. $\mathrm{C}_{19} \mathrm{H}_{10} \mathrm{AuClF}_{4} \mathrm{NPS}$, triclinic, $P \overline{1}, a=$ 8.3342(3), $b=10.2580(3), c=11.4515(4) \AA, a=97.223(1)^{\circ}$, $\beta=96.787(1)^{\circ}, \gamma=97.010(1)^{\circ}, V=955.08(6) \AA^{3}, Z=2$, $\mu=8.077 \mathrm{~mm}^{-1}, 13716$ reflections, $2 \theta_{\max } 55.98^{\circ}, 4450$ unique $\left(R_{\text {int }}=0.0630\right), R=0.0354, R_{\mathrm{w}}=0.0864$ for 293 parameters, 76 restrictions, $S=1.025$, $\max . \Delta \rho=2.580$ e $\AA^{-3}$.

$\left[\mathbf{A u}\left(\mathbf{C}_{6} \mathbf{F}_{5}\right)\left\{\mathbf{P h}_{2} \mathbf{P}(\mathbf{C N S})\left(\mathbf{C}_{6} \mathbf{F}_{4}\right)\right\}\right]$ (3). To a dichloromethane solution $(20 \mathrm{~mL})$ of $\left[\mathrm{Au}\left(\mathrm{C}_{6} \mathrm{~F}_{5}\right)(\mathrm{tht})\right](0.23 \mathrm{~g}, 0.51 \mathrm{mmol})$ was added $\mathrm{C}_{6} \mathrm{~F}_{4} \mathrm{NCSPPh}_{2}(0.2 \mathrm{~g}, 0.51 \mathrm{mmol})$ and after 1 hour of stirring the solvent was evaporated to dryness to give a white solid 3. Yield: $0.34 \mathrm{~g}$ (78.8\%). Mass spectrum: $\left[\mathrm{AuL}_{2}\right]^{+}\left(\mathrm{L}=\mathrm{C}_{6} \mathrm{~F}_{4} \mathrm{NCSPPh}_{2} \mathbf{1}\right)$ at $m / z=979.0$ Anal. Calcd for $\mathrm{C}_{25} \mathrm{H}_{10} \mathrm{AuF}_{9} \mathrm{NPS}$ : C, 39.75; $\mathrm{H}$, 1.33; N, 1.85; S, 4.24. Found C, 40.07; H, 1.35; N, 1.81; S, 4.06\%. IR: $1356 \mathrm{~cm}^{-1}$ (heterocyclic ring), 1496, 955, $793 \mathrm{~cm}^{-1}\left(\mathrm{Au}-\mathrm{C}_{6} \mathrm{~F}_{5}\right)$. ${ }^{31} \mathrm{P}\left\{{ }^{1} \mathrm{H}\right\} \mathrm{NMR}\left(\mathrm{CDCl}_{3}\right) \delta: 32.24(\mathrm{~s}) .{ }^{19} \mathrm{~F} \mathrm{NMR}\left(\mathrm{CDCl}_{3}\right) \delta:-136.45$ $\left[\mathrm{m}, 1 \mathrm{~F}, o-\mathrm{S}, \mathrm{C}_{6} \mathrm{~F}_{4}\right],-144.58\left[\mathrm{~m}, 1 \mathrm{~F}, o-\mathrm{N}, \mathrm{C}_{6} \mathrm{~F}_{4}\right],-155.04[\mathrm{~m}, 1 \mathrm{~F}$, $\left.p-\mathrm{S}, \mathrm{C}_{6} \mathrm{~F}_{4}\right],-155.53\left[\mathrm{~m}, 1 \mathrm{~F}, p-\mathrm{N}, \mathrm{C}_{6} \mathrm{~F}_{4}\right] ;-116.24\left(\mathrm{~m}, 2 \mathrm{~F}, \mathrm{~F}_{o}, \mathrm{C}_{6} \mathrm{~F}_{5}\right)$, $-157.45\left(\mathrm{t}, 1 \mathrm{~F}, \mathrm{~F}_{p}, \mathrm{C}_{6} \mathrm{~F}_{5}, J\left(\mathrm{~F}_{p}-\mathrm{F}_{m}\right)=20.0 \mathrm{~Hz}\right),-162.12(\mathrm{~m}, 2 \mathrm{~F}$, $\left.\mathrm{F}_{m}, \mathrm{C}_{6} \mathrm{~F}_{5}\right) .{ }^{1} \mathrm{H} \mathrm{NMR}\left(\mathrm{CDCl}_{3}\right) \delta: 7.95-7.25$ [m, aromatic protons].

Crystal data for 3. $\mathrm{C}_{25} \mathrm{H}_{10} \mathrm{AuF}_{9} \mathrm{NPS}$, monoclinic, $P 2_{1} / c, a=$ 8.5376(2), $b=18.7340(5), c=14.7669(4) \AA, \beta=90.757(1)^{\circ}, V=$ $2361.66(11) \AA^{3}, Z=4, \mu=6.473 \mathrm{~mm}^{-1}, 18493$ reflections, $2 \theta_{\max }$ $55.70^{\circ}, 5465$ unique $\left(R_{\text {int }}=0.0423\right), R=0.0265, R_{\mathrm{w}}=0.0583$ for 383 parameters, 123 restrictions, $S=1.040$, $\max . \Delta \rho=1.339$ e $\AA^{-3}$.

Crystal data for 2 and 3 were measured at $-100{ }^{\circ} \mathrm{C}$ using a Nonius KappaCCD diffractometer, Mo-K $\alpha$ radiation, $\omega$ and $\phi$-scans. The structures were solved by direct methods and refined anisotropically on $F^{2} \cdot{ }^{23}$ Hydrogen atoms were located in the Fourier map and refined without restrictions. Absorption correction: multi-scan.

CCDC reference numbers 292271 and 292272.

For crystallographic data in CIF or other electronic format see DOI: $10.1039 /$ b517728f

\section{Computational details for TD-DFT calculations}

The molecular structures used in the theoretical studies on $\mathrm{Ph}_{2} \mathrm{P}(\mathrm{CNS})\left(\mathrm{C}_{6} \mathrm{~F}_{4}\right) \quad \mathbf{1 a}$ and $\left[\mathrm{Au}\left(\mathrm{C}_{6} \mathrm{~F}_{5}\right)\left\{\mathrm{Ph}_{2} \mathrm{P}(\mathrm{CNS})\left(\mathrm{C}_{6} \mathrm{~F}_{4}\right)\right\}\right]$ 3a were taken from the X-ray diffraction data for $\left[\mathrm{Au}\left(\mathrm{C}_{6} \mathrm{~F}_{5}\right)\right.$ $\left.\left\{\mathrm{Ph}_{2} \mathrm{P}(\mathrm{CNS})\left(\mathrm{C}_{6} \mathrm{~F}_{4}\right)\right\}\right]$ 3, respectively. For model 1a a full geometry optimization was carried out. Keeping all distances, angles and dihedral angles frozen, single-point DFT calculations were performed on model 3a. In both the ground-state calculations and the subsequent calculations of the electronic excitation spectra, the B3LYP functional ${ }^{24}$ as implemented in TURBOMOLE ${ }^{25}$ was used. The excitation energies were obtained at the density functional level by using the time-dependent perturbation theory approach (TD-DFT), ${ }^{26-30}$ which is a DFT generalization of the Hartree-Fock linear response (HF-LR) or random-phase approximation (RPA) method. ${ }^{31}$ In all calculations, the Karlsruhe split-valence quality basis sets ${ }^{32}$ augmented with polarization functions ${ }^{33}$ were used (SVP). The Stuttgart effective core potential in TURBOMOLE was used for $\mathrm{Au} .{ }^{34}$ Calculations were performed without any assumption of symmetry for 1a and $\mathbf{3 a}$.

\section{Acknowledgements}

The D.G.I.(MEC)/FEDER (CTQ2004-05495) project is acknowledged for financial support. M. Monge thanks the MECUniversidad de La Rioja for his research contract "Ramón y Cajal". M. Montiel thanks the C.A.R. for a grant. Dr A. Avenoza is acknowledged for fruitful discussions.

\section{References}

1 W. S. Rapson and T. Groenewald, Gold Usage, Academic Press, London, 1978.

2 P. J. Sadler, Gold Bull., 1976, 9, 110.

3 K. C. Dash and H. Schmidbaur, in Metal Ions in Biological Systems, ed. H. Sigel, Marcel Dekker, New York, Basel, 1982, vol. 14, p. 179ff.

4 A. Ulman, Chem. Rev., 1996, 96, 1533 and references therein.

5 C. F. Shaw, III, in Gold: Progress in Chemistry, Biochemistry and Technology, ed. H. Schmidbaur, Wiley, New York, 1999, p. $259 \mathrm{ff}$.

6 (a) O. Crespo, E. J. Fernández, P. G. Jones, A. Laguna, J. M. López-deLuzuriaga, M. Monge, M. E. Olmos and J. Pérez, Dalton Trans., 2003, 1076; (b) G. Siasios and E. R. T. Tiekink, Malays. J. Sci., Ser. B, 1996, $17,1$.

7 T. D. Petrova, V. E. Platonov, L. N. Shchegoleva, A. M. Maksimov, A. Haas, M. Schelvis and M. Lieb, J. Fluorine Chem., 1996, 79, 13.

8 F. E. Herkes, J. Fluorine Chem., 1979, 13, 1.

9 See for instance: (a) E. J. Fernández, M. C. Gimeno, P. G. Jones, A. Laguna, M. Laguna and M. E. Olmos, J. Chem. Soc., Dalton Trans., 1994, 2891; (b) E. J. Fernández, M. C. Gimeno, P. G. Jones, A. Laguna, M. Laguna and M. E. Olmos, J. Chem. Soc., Dalton Trans., 1996, 3603.

10 (a) M. F. M. Al-Dulaymmi, A. Hills, P. B. Hitchcock, D. L. Hughes and R. L. Richards, J. Chem. Soc., Dalton Trans., 1992, 241-248; (b) M. F. M. Al-Dulaymmi, P. B. Hitchcock and R. L. Richards, J. Organomet. Chem., 1988, 338, C31; (c) M. F. M. Al-Dulaymmi, D. L. Hughes and R. L. Richards, J. Organomet. Chem., 1992, 424, 79.

11 B.-C. Tzeng, Y.-C. Huang, W.-M. Wu, C.-Y. Lee, G.-H. Lee and S.-M. Peng, Cryst. Growth Des., 2004, 4, 63.

12 K. K.-W. Lo, C.-K. Li and J. S.-Y. Lau, Organometallics, 2005, 24, 4594.

13 Y.-H. So, J. M. Zaleski, C. Murlick and A. Ellaboudy, Macromolecules, 1996, 29, 2783.

14 M. R. Haneline, M. Tsunoda and F. P. Gabbaï, J. Am. Chem. Soc., 2002, 124, 3737

15 M. A. Omary, R. M. Kassab, M. R. Haneline, O. Elbjeirami and F. P. Gabbaï, Inorg. Chem., 2003, 42, 2176.

16 C. Adachi, M. A. Baldo and S. R. Forrest, J. Appl. Phys., 2000, 87, 8049.

17 V. V. Grushin, N. Herron, D. D. LeCloux, W. J. Marshall, V. A. Petrov and Y. Wang, Chem. Commun., 2001, 1494.

18 J. Zhang, S. Kan, Y. Ma, J. Shen, W. Chan and C. Che, Synth. Met., 2001, 121, 1723 and references therein.

19 H. V. R. Dias, H.-L. Lu, H.-J. Kim, S. A. Polach, T. K. H. H. Goh, R. G. Browning and C. J. Lovely, Organometallics, 2002, 21, 1466 and references therein.

20 H. V. R. Dias, H.-J. Kim, H.-L. Lu, K. Rajeshwar, N. R. de Tacconi, A. Derecskei-Kovacs and D. S. Marynick, Organometallics, 1996, 15, 2994 and references therein. 
21 E. A. Allen and W. Wilkinson, Spectrochim. Acta, Part A, 1972, 28, 2257.

22 R. Usón, A. Laguna and J. Vicente, J. Chem. Soc., Chem. Commun., 1976, 353.

23 G. M. Sheldrick, SHELXL-97, Program for refinement of crystal structures, University of Göttingen, Germany, 1997.

24 (a) A. D. Becke, J. Chem. Phys., 1992, 96, 215; (b) A. D. Becke, J. Chem. Phys., 1993, 98, 5648; (c) C. Lee, W. Yang and R. G. Parr, Phys. Rev Lett., 1998, B 37, 785.

25 R. Ahlrichs, M. Bär, M. Häser, H. Horn and C. Kölmel, Chem. Phys. Lett., 1989, 162, 165.

26 R. Bauernschmitt and R. Ahlrichs, Chem. Phys. Lett., 1996, 256, 454.
27 R. Bauernschmitt and R. Ahlrichs, J. Chem. Phys., 1996, 104, 9047.

28 R. Bauernschmitt, M. Häser, O. Treutler and R. Ahlrichs, Chem. Phys. Lett., 1997, 264, 573 and references therein.

29 E. K. U. Gross and W. Kohn, Adv. Quantum Chem., 1990, 21, 255.

30 M. E. Casida, in Recent advances in density functional methods, ed. D. P. Chong, World Scientific, Singapore, 1995, vol. 1.

$31 \mathrm{~J}$. Olsen and P. Jørgensen, in Modern electronic structure theory, ed. D. R. Yarkony, World Scientific, Singapore, 1995, vol. 2.

32 A. Schäfer, H. Horn and R. Ahlrichs, J. Chem. Phys., 1992, 97, 2571.

33 T. H. Dunning, Jr., J. Chem. Phys., 1994, 100, 5829.

34 D. Andrae, U. Haeussermann, M. Dolg, H. Stoll and H. Preuss, Theor. Chim. Acta, 1990, 77, 123. 